\begin{tabular}{|l|l|l||}
\hline \multicolumn{2}{|c|}{ PublisherInfo } \\
\hline \hline PublisherName & $:$ & BioMed Central \\
\hline \hline PublisherLocation & $:$ & London \\
\hline \hline PublisherImprintName & $:$ & BioMed Central \\
\hline \hline
\end{tabular}

\title{
Intronic sequences
}

\begin{tabular}{|l|l|l||}
\hline \multicolumn{2}{|c||}{ ArticleInfo } \\
\hline \hline ArticleID & $:$ & 4212 \\
\hline \hline ArticleDOI & $:$ & 10.1186 /gb-spotlight-20010928-01 \\
\hline \hline ArticleCitationID & $:$ & spotlight-20010928-01 \\
\hline \hline ArticleSequenceNumber & $:$ & 283 \\
\hline \hline ArticleCategory & $:$ & Research news \\
\hline \hline ArticleFirstPage & $:$ & 1 \\
\hline \hline ArticleLastPage & $:$ & 2 \\
\hline \hline & $:$ & RegistrationDate : 2001-09-28 \\
ArticleHistory & $:$ & OnlineDate \\
\hline \hline ArticleCopyright & $:$ & BioMed Central Ltd2001 -09-28 \\
\hline \hline ArticleGrants & $:$ & \\
\hline \hline ArticleContext & $:$ & 130592211 \\
\hline \hline
\end{tabular}




\section{Jonathan B Weitzman}

Email: jonathanweitzman@hotmail.com

We are far from understanding all the rules that govern the process of RNA splicing and defining the sequence information that governs intron definition. In the September 25 Proceedings of the National Academy of Sciences, Lee Lim and Christopher Burge at the Massachusetts Institute of Technology, Cambridge, USA, describe a computational approach for investigating intron splicing (Proc Natl Acad Sci USA 2001, 98:11193-11198). They chose transcripts from five eukaryote genomes (Saccharomyces cerevisiae, Carnorhabditis elegans, Drosophila melanogaster, Arabidopsis thaliana, and human) whose exon-intron structures were well-defined. They analysed 5' and 3' splice signal motifs in short introns and used mathematical methods (Markov models and Monte Carlo simulations) to determine the amount of information required for intron recognition. While 5' and 3' splice signal sequences were sufficient to predict short introns in the fly and worm genomes ( $>90 \%$ accuracy), human and plant introns required additional transcript features, such as specific pentamer sequences within the intron.

\section{References}

1. Split genes and RNA splicing

2. Proceedings of the National Academy of Sciences, [http://www.pnas.org]

3. Massachusetts Institute of Technology, [http://www.mit.edu] 